\title{
Contribución a una filosofia de la imagen en el sistema del saber hegelianol
}

\author{
A contribution to a philosophy of image in the \\ hegelian system of knowledge \\ HARIS PAPOULIAS \\ Università del Piemonte Orientale (Italia)
}

Recibido: 28-04-2014 Aceptado definitivamente: 26-05-2014

\section{RESUMEN}

El propósito de este ensayo es discutir sobre la posibilidad de desarroyo de una ontología de la imagen a partir de las premisas teóricas del Sistema del Saber hegeliano, mostrando también su relevancia en el debate contemporáneo de los visual studies o de la Bildkritik.

\author{
PALABRAS CLAVES \\ HEGEL, IMAGEN, ROMANTICISMO, ARTE ABSTRACTO, \\ ESPIRITU SUBJETIVO, ICONOCLASTIA ENDOGENA
}

\begin{abstract}
The aim of this essay is to argument the possibility to develop an Ontology of Image, taking as a starting-point the theoretical premises of the Hegelian System of Knowledge and by doing so to show its actuality in the contemporary debate of visual studies or of Bildkritik.

Suplemento 19 (2014)

(C) Contrastes. Revista internacional de filosofía, pp. 223-248. ISSN: 1136-9922

Departamento de filosofía, Facultad de Filosofía y Letras, Universidad de Málaga

Campus de Teatinos, E-29071 Málaga (España)
\end{abstract}

1 Para las citas de las obras hegelianas, utilizaremos estas siglas: GW: Gesammelte Werke, ed. por la Rheinisch-Wesfälische Akademie der Wissenschaften y la Deutsche Forschungsgemeinschaft, Hamburg 1968 ss., seguido del num. del vol. y la pág.; W: Werke in zwanzig Bänden, ed. E. Moldenhauer y K. M. Michel, Frankfurt a.M. 1970, seguido del num. del vol. y la pág.; las ediciones españolas utilizadas e indicadas después del punto y coma son: Lecciones sobre la estética, trad. de A. Brotóns Muñoz, Madrid 1989; Ciencia de la lógica, vol. 1: La Lógica Objetiva, ed. de Félix Duque, Madrid 2011. 


\title{
KEY WORDS \\ HEGEL, IMAGE, ROMANTICISM, ABSTRACT ART, SUBJECTIVE SPIRIT, ENDOGENUS ICONOCLASM
}

\begin{abstract}
Die Betrachtung des Geistes ist nur dann in Wahrheit philosophisch, wenn sie (...) den Geist als ein Abbild der ewigen Idee begreift. ${ }^{2}$

Enz. $\$ 377 Z$
\end{abstract}

\section{UNA ONTOLOGÍA DE LA IMAGEN ¿ICONOCLASTA?}

EN ESTE RECORRIDO, NECESARIAMENTE RÁPIDO, esperamos clarificar la centralidad de un principio que debería introducirse en el corazón de cualquier ontología de la imagen: el principio de lo que podríamos denominar «iconoclastía endógena» de la imagen. La breve exposición que sigue se basa en esta convicción: la imagen, en cuanto producción artística, y su cambio a lo largo de los siglos (y en particular en su transición del romanticismo a las vanguardias históricas), no sigue dictados externos de tipo socio-político o factores observables desde otras disciplinas humanísticas, sino una propia necesidad interior. Por lo tanto, las opiniones y las investigaciones actuales podrían encontrar un terreno fértil donde crecer criticamente, únicamente en un sistema del saber, como el hegeliano, que garantiza el nexo interno de los objetos del pensamiento, y no sólo las afinidades ocasionales surgidas de tendencias efímeras. Para mostrarlo convincentemente, es necesario presentar una ontología hegeliana de la imagen firme y bien definida, ${ }^{3}$ cosa que hasta ahora no ha sido aún realizada, al menos no como ha sido hecha con otros grandes filósofos del idealismo alemán. ${ }^{4}$

Una ontología hegeliana de la imagen tendría exactamente este objetivo: indagar en la estructura de la imagen por aquello que es en sí misma y no sólo por sus funciones culturales. En otras palabras, creemos que la imagen ha seguido el curso de su propia esencia, es decir, que es un momento de la reflexión de la esencia del Ser, antes que una simple imagen artística. Esta última, en este sentido, no es más que una de las declinaciones posibles entre otras tantas, como

2 «El tratamiento del Espíritu, es verdaderamente filosófico, únicamente cuando (...) concibe el Espíritu como una Imagen Eterna de la Idea».

3 A tal contribución para la formación de una ontología hegeliana de la imagen, está dedicado también mi proyecto de investigación en la Universidad del Piamonte Oriental, bajo la dirección del Prof. Maurizio Pagano.

4 Como Fichte, que no elaboró una filosofía del arte a diferencia de Schelling o Hegel y aún así es ya una opinión compartida por todos que su Wissenschaftlehre puede ser leída incluso como una Bildwissenschaft. Me limitaré a dos trabajos recientes y de alto nivel, donde vienen expuestas también las tesis de los autores alemanes que han dado el inicio a tal tipo de investigación: cfr. A. Bertinetto, La forza dell'immagine. Argomentazione trascendentale e ricorsività nella filosofia di J.G. Fichte, Milano 2010; M. Ivaldo, L'immagine immaginante, en: Aa.Vv., Ontologia dell'immagine, Roma 2012, pp. 97-110. 
precisamente pueden ser las imágenes mentales, las representaciones conscientes o inconscientes, las imagenes oníricas o las imágenes científicas, los símbolos sagrados de la religión, y así sucesivamente.

Uno de los problemas, de segundo orden desde el punto de vista sistemático, pero fundamental para aquellos interesados en los resultados de la filosofía hegeliana en este campo y a su uso crítico en las cuestiones de la imagen en el siglo XX, es el interpretativo: ser capaces de alcanzar las fuentes de la contemporaneidad bajo un punto de vista hegeliano, sin por ello traicionar ni la especificidad de lo contemporáneo, ni la filosofía hegeliana en su conjunto.

Desde Platón a Gadamer, la imagen es reconocida por todos como el elemento intermedio entre los fenómenos y la esencia de las cosas. Además, refleja bien el carácter gnoseológico general de cualquier filosofía: para Platón era un doble y una disminución ontológica; ${ }^{5}$ para Gadamer, por el contrario, un «aumento del ser». ${ }^{6}$ Entre ellos ha habido muchos otros: para Descartes no era nada, ${ }^{7}$ para Berkeley lo era todo, ${ }^{8}$ y así sucesivamente.

Aún hoy no sabemos lo que pensaba Hegel sobre esta cuestión. Al que trata de desarrollar una ontología de la imagen, lo único útil que puede encontrar en la Estética es la concepción más amplia de la imagen. El párrafo dedicado precisamente a la imagen, de hecho, podría ser llamado «la imagen poética» (cfr. W13, 523; 300).

Por otro lado, el nombre de Hegel ha estado siempre de actualidad en el ámbito estético, en particular cuando se trataba de la infame cuestión de la «muerte del arte». Además, se consolidó también, indirectamente, un Hegel

5 La cuestión del estatus ontológico de la imagen en Platón es muy amplia y diferentemente interpretable en el curso de la historia filosófico-artística de Occidente. En cuanto a la devaluación ontológica de la que estamos hablando aquí, basta referir a la conclusión del libro

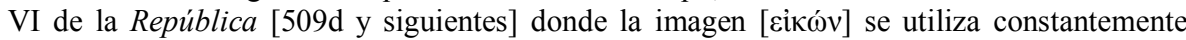

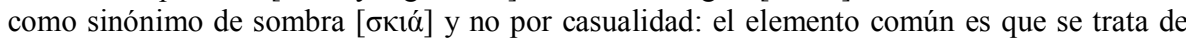
un doble de alguien y nunca de la cosa en si misma. Sin embargo, no faltan estudios que afirman los aspectos positivos de la imagen en la filosofía platónica; cf. G. Mouroutsou, Eikóv bei Platon: Die Metaphysik des Bildes, in: Das Bild als Denkfigur. Funktionen des Bildbegriffs in der Geschichte der Philosophie, München 2010, pp. 33-49.

6 Cfr., H.-G. Gadamer, Wahrheit und Methode: Grundzüge einer philosophischen Hermeneutik, en: Id. Gesammelte Werke, Bd.1: Hermeneutik I, Tübingen 1986, p. 145.

7 Al menos así según Gilbert Durand (La immaginazione simbolica, Milano 2012, p. 28ss) el cual se refiere a la Tercera Meditación cartesiana y la conciencia como la única verdadera imagen de Dios.

8 Cfr., G. Berkeley, Tratado sobre los principios del conocimiento humano, §33.

9 Recientemente se celebró un convenio en Roma sobre el tema, organizado por el Goethe-Institut y la Universidad de Roma Tre: Da Hegel ad oggi. Sviluppi della riflessione estetica tedesca e italiana dopo la morte dell'arte / Von Hegel bis heute. Entwicklung der deutschen und italienischen Ästhetik nach dem Ende der Kunst, 16-18 dic. 2013. El origen de este debate es probable que se remonte a la tesis de Benedetto Croce Estetica come scienza dell'espressione e linguistica generale, Milano $2005\left(1902^{1}\right)$, p. 386s. Para una bibliografía 
hostil a los nuevos desarrollos artísticos, no tanto por el mito de la «muerte del arte», como por otros mitos con mucho más control sobre el imaginario artístico colectivo, como por ejemplo la atribución a Hegel de un gusto clásico y la catalogación de su estética como una estética clasicista por excelencia. ${ }^{10}$

La filosofía hegeliana deberá ser cuestionada no sólo sobre el modo concebir una corriente artística del pasado, o sobre el específico modo de crear imágenes, sino en primer lugar sobre qué es la imagen en general. De esta pregunta fundamental dependerá su actualidad estética.

¿Qué sabía realmente Dan Flavin de William Ockham cuando hizo su Nominal Three, dedicado al filósofo inglés? ¿Se puede afirmar la actualidad de Ockham sólo porque hoy es citado por un artista de éxito? Hegel no goza de una obra de arte contemporáneo dedicada a él. El problema de fondo, entorno a la actualidad o no de un filósofo, creo que es éste: que una teoría filosófica no es como una novela que influye en las generaciones; no puede convertirse ni en un best-seller, ni en un guión de película de Hollywood. Una teoría filosófica, o es verdadera, o no es; y poco cuentan los ejemplares vendidos o la cantidad de citas. Aunque «la novela de la conciencia» no puede convertirse en una película, no tiene que sorprender el descubrimiento de su lógica en las estéticas de vanguardia de la creación cinematográfica. ${ }^{11}$

detallada, consultese Arte e morte dell'arte, a c. di P. Gambazzi e G. Scaramuzza, Milano 1997; Sin embargo, observamos que hay ejemplos de este malentendido, ya desde los contemporáneos de Hegel. Es característico el ejemplo del compositor F. MendelssohnBartholdy, que ya en aquella época pensaba que Hegel hablaba de la «muerte del arte» como el fin de la producción artística; la noticia la recoge Nicolin en su Hegel in Berichten seiner Zeitgenossen, Hamburg 1970, n.669, 665; cit. en la introducción de P. D' Angelo en el vol. Lezioni di estetica de Hegel de 1823, Roma -Bari 2005, p. XXXI , n. 24, la cual señalamos para profundizar en el argumento.

10 En Italia, quizá uno de los principales responsables ha sido el historiador y crítico de arte Lionello Venturi, quien con una expresión desacertada llama a Hegel un «idealista Olímpico» que habría incluso impedido el desarrollo del arte mismo; cfr., Id, Storia della critica d'arte, Torino 2002 (1936'), p. 201.

11 Es el movimiento de lo negativo y el movimiento de su superación, como es descrito por Hegel lo que ha inspirado a un gran maestro del cine como Ejzenštejn. «Ejzenštejn atribuye al montaje la misma relación de muerte y renacimiento» como si fuera el movimiento de la conciencia en Hegel: cfr. M. Pezzella, Estetica del cinema, Bologna 20012, p.110. Como dice Pezzella, en este principio formal de desmembramiento y de reunificación está la diferencia entre el cine crítico expresivo y el espectacular. Mientras que en el primero se destaca la discontinuidad, en el segundo se oculta con el propósito de crear la ilusión de una realidad «que no tenga grietas» (Ibid., p.110s). Otro caso de estética cinematográfica es también significativo: Jean -Luc Godard señaló a Hegel como la inspiración para una de sus obras maestras de montaje Une histoire seule (segunda parte de su Histoire(s) du cinema); cfr., las declaraciones hechas por el director durante la primera proyección italiana de las Histoire $(s) d u$ Cinema en Bolonia en 1998, en: J.-L. Godard, Histoire(s) du cinema, Cineteca Bologna, edición de R. Censi, Bologna 2010, p.7. 
Lo mismo ocurre con la música, como muestra el excelente trabajo de Jere Surber. ${ }^{12}$ En este estudio, además de las valiosas informaciones que encontramos sobre la relación de la filosofía hegeliana con la nueva música modernista (de Mahler a Schoenberg), hay otro elemento que para nosotros constituye el centro de la vida de las imágenes: la cuestión iconoclasta. El autor habla de ello cuando se refiere al carácter del arte modernista, definiendo este último como el resultado de la progresiva eliminación de la distinción entre el arte y la filosofía, como ya sucede a partir de Hegel. ${ }^{13}$ Esta observación justa y aguda, se presta de manera ejemplar para puntualizar nuestra tesis: no sólo Hegel está en el comienzo del proceso que hará madurar una estética modernista iconoclasta (esto no es más que la envoltura del principio iconoclasta), sino que sólo en Hegel una iconoclastía endógena se pone como el principio regulador de la vida misma de la imagen — y prestemos atención: de cualquier imagen-.

En los años setenta, apareció una historia del arte diseñada para dar cuenta de esta revolución. Robert Rosenblum, con su obra Modern Painting and the Northern Romantic Tradition: Friedrich to Rothko $\left(1975^{1}\right)^{14}$ dio forma completa a los estudios iniciados unos años antes en forma de seminarios en diversas universidades. Por una «astucia del Espíritu», en los mismos años, en Italia, otro gran historiador del arte, Francesco Arcangeli (1915-1974), daba lecciones en

12 Cfr., J. Surber, Art as a Mode of Thought: Hegel's Aesthetics and the Origins of Modernism, in: Hegel and Aesthetics, edición de William Maker, New York 2000, pp. 45-59.

13 Cfr., Ibid., p. 47.

14 La Pintura moderna y la tradición del Romanticismo nórdico: de Friedrich a Rothko, Madrid 1993; en España se ha dicho que Rosenblum no ha sido el primero en apoyar esta tesis (cfr. G. Sollana, Rosenblum y los orígenes románticos de la abstracción, en: Aa. Vv., El arte abstracto. Los dominios de lo invisible, Fundación Cultural Mapfre Vida, (2005), p. 256). Aunque esto no es decisivo para nosotros, sólo tengamos en cuenta que el trabajo de Rosenblum no tiene comparación con ningún "paralelismo" ya propuesto en pasado, debido a su sistematicidad y exhaustividad. En una entrevista, Rosenblum indica Greenberg - el historiador del arte que sería su precursor en los años 50, según Sollana - precisamente aquel que obstaculizó la concepción del arte como la suya (cf. Una entrevista con Robert Rosenblum, en: catálogo de la exposición La abstracción del paisaje. Del romanticismo nórdico al expresionismo abstracto (publicado por las ed. de la fundación, Madrid 2007, p.237). Así como tampoco es válida la presunta anticipación de Barnett Newman, con su ensayo sobre lo sublime, porque además del vocablo «sublime» el cual se refiere a una larga tradición secular, de hecho poco tiene que ver con ella, y menos aún con la tradición romántica. Newman, a diferencia de lo que Rosenblum argumenta, no reclama ninguna tradición para el arte abstracto, sino que por el contrario, acusa al arte europeo de estar demasiado atado a dicha tradición, y reclama para sí la primacía absoluta de un nuevo comienzo (cf. su ensayo en cuestión The Sublime is Now (1948); tr.it. Il sublime è adesso, en: La scuola di New York, edición de V. Birolli, Milano 2007, pp. 49-54). Lo central es que Rosenblum no ignora todo esto (como cree Sollana, cfr., op.cit, pp. 265ss.) y es por ello también que busca las raíces americanas del expresionismo abstracto, en lugar de buscarlas en el viejo continente. 
las que se desarrolló la misma hipótesis fundamental que sentó las raíces del arte abstracto o informal en el romanticismo del siglo XIX. ${ }^{15}$

El trabajo de estos pioneros no fue tan fácil como puede parecer a primera vista. No se trataba sólo de relacionar vagas intuiciones y sentimientos comunes entre las dos épocas, sino de encontrar relaciones formales compartidas y mostrar su afinidad expresiva, además de su contenido. A pesar de algunas críticas que aún hoy surgen esporádicamente, estas lecturas de la historia del arte se consideran una adquisición importante para nuestra conciencia, y no por casualidad se celebran regularmente por muchas instituciones en el mundo. ${ }^{16}$

Al comienzo de su trabajo, Rosenblum, trata de escapar de la categoría de «pseudomorfosis» de Panofsky, ${ }^{17}$ insistiendo en el hecho de que la analogía de las estructuras formales entre Friedrich y Rothko, por ejemplo, es «el resultado de una analogía de sensibilidad y de intención». Si en el curso de su trabajo el historiador tiene éxito, ¿no deberíamos buscar nosotros la afinidad y la comunión, en el elemento en que «afinidad» $\mathrm{y}$ «comunión» lo son por antonomasia, o sea en el Espíritu y en el concepto? Las palabras de Arcangeli indican bien la apertura de un campo para la investigación estético-filosófica, cuando escribe: «Creo desde hace mucho tiempo que una similitud formal nunca es meramente formal, sino que implica, aunque sea en condiciones históricas diferentes, similitudes de ideas, de costumbres o de calidez humana.»> ${ }^{18}$

\section{DEL ROMANTICISMO A LA ABSTACCIÓN: DEL ARTE AL PENSAMIENTO}

«Como el filósofo griego, obedeciendo al supuesto orden de la razón, condenó la mimesis y la poesía homérica, para él tan queridas, así el filósofo alemán no quiso escapar a la necesidad lógica de su sistema y declaró la mortalidad, o mejor dicho, la muerte ya avenida del arte». ${ }^{19}$ Benedetto Croce no es un lector

15 Cfr., Francesco Arcangeli, Dal Romanticismo all'informale. Lezioni accademiche 1970-71, Bologna $2005\left(1976^{1}\right)$.

16 No quiero referirme a grandes centros internacionales como los museos de Nueva York o la Tate de Londres, que en varias ocasiones han promovido estas exposiciones. Centrándonos en los dos maestros que acabamos de mencionar y en lo que se refiere a nuestros países, podríamos señalar dos iniciativas importantes sobre el tema. En Italia, en 2006, en el Museo de Arte de la ciudad de Ravenna se realizó la exposición titulada Dal Romanticismo all'informale. Omaggio a Francesco Arcangeli (cat. ed. por C. Spadoni, Milano 2006). En octubre de 2007 la Fundación Juan March de Madrid dedicó a la memoria del historiador estadounidense - recientemente fallecido - la exposición La abstracción del paisaje, cit.).

17 Es decir, en palabras de Rosenblum, la «aparición fortuita, en diferentes momentos de la historia del arte, de obras cuyas estrechas similitudes formales ocultan el hecho de que su significado es completamente diferente»; para la noción de pseudomorfosis, en cambio, cfr. E. Panofsky, Tomb Sculpture, New York-London 1964, pp.25s.

18 Cfr., F. Arcangeli, op. cit., p. 37.

19 B. Croce, Estetica op. cit., p. 386. 
superficial de Hegel como lo han sido muchos, incluso grandes filósofos, después de él. En este pasaje, afirma claramente el anuncio hegeliano de la muerte del arte. Pero no sólo se dice eso. Se hace un paralelismo entre él y el filósofo griego (podría ser cualquier griego de Platón a Plotino, poco importa aquí). Ambos condenan el arte por un presupuesto lógico, y no por un prejuicio cualquiera. De hecho, el griego no condena el arte, sino como bien advierte Croce, la mimesis y la poesía homérica. La referencia sería, entonces, al carácter de la educación que el joven debe recibir en el estado ideal de la República platónica (pero como ya se ha dicho, también podría referir al camino solitario de Plotino, «como alguien que se introduce en el sagrario del templo, dejando atrás las estatuas». ${ }^{20}$ ) Vale la pena, sin embargo, intentar leer estas proposiciones diferentemente, moviéndonos con cuidado entre las líneas.

Hegel, confrontado con esta tradición de origen griego, que ama el arte, que vive produciendo arte del más alto nivel, está a la vez a la cabeza de una tradición que condena la mimesis y la mitología. Podemos decir claramente que Hegel está en la cumbre de un filón iconoclasta que va desde los presocráticos a la modernidad, atravesando subterráneamente toda la historia de Occidente. ${ }^{21} \mathrm{Y}$ no nos referimos aquí a aquella iconoclastía banal, científica, en el sentido de la nueva ciencia cartesiana a la que se refería Durand. Es ingenuo tratar un científico como iconoclasta sólo porque traduce el movimiento en relaciones matemáticas.

Si nos detenemos aquí más de lo debido no es algo casual: se trata de reformular la concepción de lo que significaba la iconoclastía en el pasado, con respecto a un nuevo modelo de pensamiento. Croce dijo bien: el griego obedeció a la razón; el alemán obedeció a la lógica del Sistema de Saber. Y ambos han condenado un cierto arte: los griegos la mimesis y Hegel el sentimentalismo, la arbitrariedad y el capricho romántico. Croce, de alguna manera, lo especifíca un poco más adelante, y este paso no debe ser separado de aquel con el que empezamos: «El romanticismo y el idealismo metafísico habían puesto el arte tan arriba, $\tan$ en las nubes, que terminaron por darse cuenta de que, tan en alto, este no servía ya más para nada». ${ }^{22}$ Aquí está desvelado todo el misterio de la muerte del arte.

En resumen, tenemos que distinguir al menos tres formas de «muerte del arte», cada una de ellas merece atención por derecho propio: se puede hablar de «muerte del arte» (a) por un (pseudo-) racionalismo anti-artistico o anti-estético;

20 Cfr., Plotino, Enéadas, VI, 9, 11; obvia alusión a la primacía de la filosofía como conocimiento de lo divino, en comparación con las artes plásticas.

21 Alain Besançon tiene el gran mérito de haber puesto a Hegel de relieve - entre pocos filósofos modernos cuidadosamente elegidos - en la historia intelectual de la iconoclastia, cfr. L'Image interdite, une histoire intellectuelle de l'iconoclasme, Paris 1994; tr.esp. La imagen prohibida, Madrid 2003.

22 B. Croce, op. cit., p. 387. 
(b) por un auto-agotamiento interno — como en el caso de los románticos--; (c) por una auto-superación —como creemos que sucede en el caso hegeliano. ${ }^{23}$

Centrando nuestra atención sobre el arte del siglo XX, podemos ver la eficacia de esta división tripartita. Al primer caso podrían pertenecer el realismo y el arte de masas. Es inútil atribuir el asesinato del arte a Hegel; basta ver el arte del estado estalinista, para cuya consolidación - y esto hay que subrayarlo- no se ha empleado un «asesinato teórico» sino una verdadera persecución concreta, sistemática y brutal de los grandes artistas del primer período revolucionario en Rusia. $^{24}$

El auto-agotamiento interior del arte, posee a su vez al menos dos aspectos históricos importantes: aquel aspecto romántico que Hegel crítica en sus contemporáneos: el arte de su círculo murió de «tuberculosis del espíritu», ${ }^{25}$ de una mala ironía con la que se autoconsume. ${ }^{26}$ Después de 1945 , otra corriente impor-

23 G. Scaramuzza, en su Il tema della morte dell'arte nell'Estetica di Hegel (en: Problemi del Romanticismo, edición de U. Cardinale, Milano 1983, p.234s.) evidenció tres significados según los cuales se puede entender la muerte del arte y que no se alejan de los nuestros; precisamente el sentido «histórico-descriptivo», según el cual ninguna producción sería ya posible; el «histórico-valorativo» que declararía un cierto arte como no valido, no a la altura de su misión; y por último aquel por el cual el arte expresaría «desde su propio interior una exigencia de reflexión». Significativa es también la distinción hecha por el erudito español J. A. Rodríguez Tous de dos sentidos diversos del «fin del arte»: uno en sentido de «Ende» y uno de «Zweck»: cfr. Id., Idea estética y negatividad sensible. La fealdad en la teoría estética de Kant a Rosenkranz, Barcelona 2002, p. 282.

24 Cfr. el cat. de la exposición «La Caballería Roja. Creación y poder en la Rusia soviética de 1917 a 1945», Madrid, 7 Oct. 2011 - 15 Ene. 2012.

25 Hegel se refería irónicamente a los románticos que murieron no tanto por la tuberculosis real, como Novalis, si no por la «consunción (Schwindsucht, tuberculosis) del espíritu»; cfr. W13, 211; 120.

26 En este asunto, como en muchos otros, Hegel sigue siendo mal entendido. Hay que distinguir, en mi opinión, al menos dos formas de ironía en Hegel: una, de fracaso, propia de los románticos, por la que «lo sustancial se evidencia como lo nulo» (W13,98; 52); la otra, en cambio, podría ser deducida de la opinión de Hegel sobre Solger, ya que nos parece obvio que Solger no pueda ser rebajado al nivel de otros románticos. Si una de las principales aportaciones de Solger fue precisamente el enfoque sobre el concepto de ironía, debemos explicar ¿por qué Hegel elogia a su predecesor berlinés, al mismo tiempo que ataca ferozmente a otros teóricos de la ironía? Se entiende así que la respuesta se encuentra en un doble sentido de la ironía. Diego Bubbio confirma esta distinción entre la ironía de Solger y aquella de los románticos: «Solger's dialectic implies a notion of irony that is different from Romantic irony» (cfr. Id., Solger's notion of sacrifice as double negation, in: The Heythrop Journal, (2009), p.210). La ironía romántica estaría basada en un individualismo absoluto y subjetivismo psicológico, donde el Yo se pone a sí mismo para luego auto-destruirse, para Solger en cambio, «ni el Yo es absoluto, ni el finito es puesto por el Yo y, fundamentalmente, no hay superación dialéctica de lo finito»; Cfr. también D. Hernández Sánchez, La ironía estética. Estética romántica y arte moderno, Salamanca 2012, p.61: «La crítica de Hegel permite ver los dos modos fundamentales para entender la ironía, el «positivo» y el «negativo» (...)». 
tante del arte contemporáneo muere claramente de auto-agotamiento. Rothko lo advirtió acertadamente; pero lo dijo con claridad Ad Reinhardt y todo el círculo de los críticos que lo rodeaban y de los cuales nacería a continuación el arte conceptual. ${ }^{27}$ El conocido historiador del arte contemporáneo Denys Riout escribe de este modo sobre las Black Paintings de Reinhardt: «Sus «pinturas negras» han eliminado todo lo que podría ser pintura antes de experimentar el monocromo, «muro absurdo, mudo y ciego» (...). Por ello son verdaderamente las Ultimate Paintings realizables. En su insuperabilidad, ellas implican el silencio o la repetición». ${ }^{28}$ ¿Y qué hay detrás de esas pinturas, es decir, detrás de la forma de su expresión? Riout justamente señala que «la satisfacción estética cede su lugar a una investigación ontológica». ${ }^{29}$

Uno de los elementos que marcan la transición de un arte del autoagotamiento a uno de auto-superamiento, es el elemento religioso. En las relaciones entre arte y religión en la filosofía hegeliana, se entiende bien como las tres formas supremas del espíritu no están en el orden de simple sucesión. Los pasajes en los que una presupone a la otra son muchos. No se puede ir del arte clásico al romántico sin un profundo cambio de la concepción de lo divino y de la relación de la conciencia con ello. Cuestiones como la encarnación, la muerte de Dios, la libertad de la persona, la mirada «reformada» sobre el valor del arte inspirado por la doctrina luterana, son sólo algunos de los presupuestos de los cambios epocales que, según Hegel, es necesario hallar en el gran arte y en su misión. Por supuesto, como muchos suelen repetir, Hegel veía en la pintura holandesa la mundanización de los grandes temas religiosos. No es ya un goce proyectado en el más allá, sino en lo humano y cotidiano. Sin embargo, esta mundanización tiene poco que ver con el nihilismo del siglo XX, ya que es lo divino lo que se manifiesta en la vida y no una vida desprovista de lo divino. Hegel escribe: «El mundo romántico [y «romántico» para él aquí es «cristiano»] sólo tenía que llevar a cabo una obra absoluta, la propagación del cristianismo, la activación del espíritu de la comunidad». ${ }^{30}$ Esta idea vuelve insistentemente en Hegel y desmiente así nuestra habitual manera de pensar que el arte debe

27 Cfr., los escritos de A. Reinhardt, Art as Art. The selected writings, ed. de Barbara Rose, Berkeley-L.A 2007; Como muestra Riccardo Venturi (Black paintings. Eclissi sul modernismo, Milano 2008, p.54; remitimos a este estudio también para una exposición actualizada de la crítica de arte de aquel momento) basta prestar atención a los títulos de los cuadros de Reinhardt para entender lo que tenía en mente: «ultimate painting», "anonymous painting», etc. Según algunos, sería precisamente este agotamiento del arte (de la pintura) el que lleva al nacimiento del arte conceptual. Venturi resume así las ideas de otro protagonista de la época, J. Kosuth, sobre el trabajo de Reinhardt: «los Black paintings de Reinhardt han conducido a la pintura a su cumplimiento, a su agotamiento (...)»; Ibid., p. 67 n.142.

28 Cfr., D. Riout, Qu'est-ce que l'art moderne?, Paris 2000; tr.it. L'arte del ventesimo secolo, Torino 2002, p. 89.

$29 \mathrm{Ibid}$.

$30 \mathrm{~W} 14,212 ; 431$. 
ceder su puesto a la religión. Aquí es la religión quien se ofrece al arte, y esta última, a través de sus obras, constituye la comunidad y difunde el Espíritu.

Que el arte ya no sirva para provocar nuestra genuflexión, ${ }^{31}$ no quiere decir que no sirva de nada. De hecho, tal vez deberíamos leer detrás de esta imagen de orgullo protestante la intención de atribuir al arte un carácter aún más esencial; no sirve para hacer que nos arrodillemos, pero tal vez para hacernos pensar, porque esto es el carácter de la modernidad: el ser consciente de que ningún culto exterior pueda satisfacer el ánimo que en cambio quiere entender. ${ }^{32} \mathrm{Sin}$ embargo, «hacer pensar» no significa pensar ya en modo filosófico o científico. Es siempre en la sensación donde el arte trabaja, sólo que ahora ya no se mantiene anclado a él. ¿Qué tiene en común un crucifijo de Friedrich con uno de Velázquez? Ambos se ofrecen a la sensibilidad (¿cómo podría ser de otra manera?), pero, mientras que el español representa la carne sufridora del Hijo de Dios ${ }^{33}$ el alemán no representa más que su sombra en medio de un paisaje montañoso. No hace falta llegar a Malevich para preguntarse si aún se puede rezar frente a este tipo de pinturas. ${ }^{34}$ La vanguardia abstraccionista, está ya aquí presente. Para la nueva mentalidad protestante, no es la carne la que despierta el sentimiento, sino el signo, el darse al pensamiento rememorante. Cuando Hegel privilegia el signo respecto al símbolo, no es que subestime el arte, como se dice trivialmente, sino que privilegia una manera de pintar como la de Friedrich o de Carus, donde cada elemento remite a algo más allá de sí mismo, en oposición a aquel romanticismo catolizante de los Nazarenos, elogiado sin embargo por Schlegel. ${ }^{35}$ Y quién sabe si Friedrich los tenía a ellos en mente cuando hacía la defensa de la estética de Hegel contra un pintor de estilo "griego-italiano», declarando que «esta opinión sobre el arte [que se opone a la hegeliana] (...) confieso que no me agrada. De una obra de arte exijo elevación del espíritu e impulso religioso (...)». ${ }^{36}$ Ahora bien, la elevación del espíritu ciertamente no podría ser el arrodillarse, sino más bien la transposición en el cuadro de un reino espi-

31 Cfr., W13, 142; 79.

32 Hegel lo había percibido y tematizado desde los así llamados «escritos juveniles», cuando hablando de la última cena, decía: «algo divino se prometió, y se ha disuelto en la boca»; cfr. W1, 369 .

33 Son bien conocidas las palabras de Unamuno, llenas de pasión, dedicadas a este crucifijo de Velázquez y a la carnalidad de lo divino («Sólo comerte nos apaga el ansia,/pan de inmortalidad, carne divina./Nuestro amor entrañado, amor hecho hambre»), donde la palabra clave es precisamente esta: carne; «carnalidad» que va más allá de la simple petición de «visibilidad» de los Padres griegos; donde el crucifijo bizantino, se representa ya, podríamos decir, resucitado, hierático, el crucifijo latino es carne sufriente.

34 Pregunta irónica de P.N. Evdokimov en su Teologia della bellezza, Milano 1990, p. 102.

35 Su hijastro, Philipp Veit (1793-1877), hijo de la mujer Dorothea de su primer matrimonio, ha sido uno de los protagonistas del movimiento.

36 Cfr., C. D. Friedrich, Scritti sull'arte, tr.it. de L. Rubini, Milano 2001, p. 75. 
ritual interior. Del mismo modo, el paisaje natural, para Friedrich y para la mejor tradición del Norte (y que convendría dejáramos de llamar con la indicación geográfica, ya que en juego no están las latitudes, sino la sensibilidad Luterana de lo sagrado) no es más que la ocasión para hacer emerger la divinidad y lo sublime del espíritu. Todo lo contrario a cualquier pobre concepción naturalista del paisaje. ${ }^{37}$

Hegel había captado muy agudamente este principio interior del arte, en plena dinámica explosiva de sus consecuencias, cuando señaló que «en las formas de la belleza clásica no puede representarse a Cristo flagelado, con la corona de espinas, arrastrando la cruz al lugar del suplicio, clavado en la cruz, agonizante en el tormento de una lenta muerte de martirio $» .{ }^{38}$ No sólo es aquí donde encontramos el punto de inflexión histórico que pronto permitirá la teorización de una «estética de la fealdad», sino que aquí están también las raíces de la desaparición de la figura humana en la pintura del siglo XX: «Cristo debe tener por una parte interioridad y espiritualidad de todo punto universal, por otra personalidad y singularidad subjetivas; ambos aspectos contrastan con la beatitud en lo sensible de la figura humana.»» ${ }^{39}$ Se tiende a considerar «simbólica» la obra de pintores como el gran C.G. Carus. Pero no hay nada de «simbólico» en la obra de alguien que está obsesionado con la idea de una continua excedencia del infinito en lo

37 De hecho, Hegel admite el valor sublime del paisaje, sólo que quiere precisar que la verdadera calidad en la obra de arte no es natural, sino que «reside en nuestra representación y en nuestro propio ánimo»; cfr. W13, 177; 99. Tanto en la cuestión de la muerte del arte, como en la de la belleza natural, la lógica hegeliana permanece la misma. Su intención no quería ser una prohibición de la representación concreta de la naturaleza, sino la denuncia de una falsa atribución a la naturaleza de algo que en realidad es sólo propio del espíritu, como lo bello (o cualquier otra categoría estética). Si en el arte del pasado, Arcadia tenía que ser realmente un lugar similar a la región montañosa del Peloponeso, en el arte romántico la naturaleza sirve sólo como ocasión de invocación divina, de desmaterialización de lo finito, de hundimiento en el Yo; ¿quién puede pensar en una «naturaleza-natural» al leer el Winterreise de W. Müller? P. Collini, (en su Iconolatria e iconoclastía nella letteratura romantica, Pisa 2004) encuentra en el paisaje invernal un topos iconoclasta del romanticismo; tesis esta que nos sorprende felizmente, incluso a la luz de las observaciones que seguirán sobre el valor de la iconoclastia. Acerca de lo «natural» en Friedrich, cfr. los cap. dedicados a la mística del paisaje en el ensayo de A. De Paz, Lo sguardo interiore. Friedrich o della pittura romantica tedesca. Liguori, Napoli 1986; centrando el núcleo de la cuestión, es decir, la transfiguración de lo natural a en lo espiritual dentro y por obra del paisaje pictórico, una exposición del Museo del Romanticismo de Madrid fue llamada Los espejos del alma, Paisaje Alemán en el romanticismo, Museo Nacional del Romanticismo, Madrid, dic. 2012 - mar. 2013.

$38 \mathrm{~W} 14,153 ; 396$.

$39 \mathrm{~W} 14,150 ; 395$; en otro lugar, hemos indicado el argumento teológico de la muerte de Dios en Hegel, como el principio metafísico, responsable de esta revolución estética: cf. H. Papoulias, Thanàtô thànaton patêsas. Prospettive estetiche del problema teo-logico della Morte di Dio in G.W.F. Hegel, in: Davar. Crocifissioni, Reggio Emilia 2009-10 (5). 
finito. El símbolo necesita la sensibilidad; los grandes artistas tienen la necesidad de sobrepasarla. ${ }^{40}$

Esta pintura, que poco a poco comienza superarse a si misma, hemos dicho que se parece más a un signo que a un símbolo. Véanse las acuarelas de J.M.W. Turner: cuatro pinceladas no son suficientes para dibujar un barco para ninguna academia del mundo. Hoy en día no se puede entender lo radical de una experimentación cromática en los círculos conservadores como aquel de la Academia Británica de entonces. Ningún elemento formal en sí mismo la puede justificar, sino la obsesión del pintor por el valor metafísico de la luz que le «ordena» desestructurar y reconstruir la total percepción visual del mundo. ${ }^{41}$ Las imágenes de Turner no se pueden mirar; sólo se pueden vivir desde el interior; tal vez porque se trata de imágenes sensibles de lo que Duque llama «esplendor sin nada en el fondo, sin hypokeimenon ${ }^{42}$ y que Kojève también pensaba como imágenes «ausentes de aportación subjetiva». ${ }^{43}$ Cuando la mirada pierde su capacidad de aferrarse a las formas (Formen) materiales, ahí gana la forma (Gestalt) de la Inteligencia. Mediar este salto era el deber de todo gran arte, y por lo tanto no debe sorprendernos cuando un especialista como Riout indica la conexión entre la estética bizantina (que no casualmente podemos encontrar en la estética del hegeliano A. Kojève), Hegel y las vanguardias abstraccionistas. Como ya él acertadamente indicó, el marco conceptual entre Hegel y los otros es diferente, pero la idea de que el arte manifiesta lo que de otro modo permanecería inaccesible a los sentidos es el elemento que los acomuna, y retorna a ser el punto central alrededor del cual gira la estética de la abstracción contemporánea. ${ }^{44}$

40 Escribe Carus: «Si subes a la cumbre de una montaña y observas las distintas alturas, el curso de los ríos y cualquier otra maravilla que se ofrece a tu mirada, te invade un sentimiento de sereno recogimiento, te sientes perdido en la infinitud del espacio, tu Yo desaparece, tú no eres ya nada, Dios es todo»; cfr., C.G. Carus, Neun Briefe über Landschaftsmalerei; tr.it. Lettere sulla pittura di paesaggio, ed. A. Nigro, Pordenone 1991, p. 18s.

41 Hegel, durante toda su vida, defendió la Teoría de los colores (1810) de Goethe en contra de la teoría de Newton. Turner también era un partidario convencido y a ella le dedicó uno de sus cuadros más sublimes, The Morning after the Dilonge (1843). John Ruskin, su apasionado defensor, nos refiere que sus últimas palabras fueron «The Sun is God», frase que por si sola puede explicar el salto cualitativo de su pintura respecto a aquella de sus contemporáneos. Véase la obra monumental de J. Ruskin, Modern Painters, 1843-1860; en castellano, véase J. Ruskin, Sobre Turner. Edición de Dinah Birch, México 1996.

42 Expresión sugerente, ésta, que el filósofo español emplea precisamente en su explicación de la parte de la Lógica hegeliana que en breve tocaremos; cfr., F. Duque, Il fiore nero, Milano 1995, p.23.

43 Cfr., A. Kojève, Les peintures concrètes de Kandinsky, Bruxelles 2001; tr.it. I dipinti concreti di Kandinsky, in: Id., Kandinsky, edición de M. Filoni, Macerata 2005, p. 38.

44 Cfr., D. Riout, op.cit., p. 272; para una amplia reflexión sobre la relación entre la estética bizantina y la abstracción, cf. G. Di Giacomo, Icona e arte astratta, Palermo 1990. 
Toda la estética de Hegel podría ser leída como una de las poquísimas obras del siglo XIX de filosofía sistemática que abre el camino a esta «liberación» del arte y del artista mismo. Hegel escribe: - como si estuviera hablando de los artistas de vanguardia en vez de los del siglo XIX - : «De este modo, ahora el artista, cuyos talento y genio están para sí liberados de la anterior limitación a una forma artística determinada, tiene a su servicio y a su disposición cualquier forma así como cualquier material.» ${ }^{45}$ Esta intuición hegeliana está en la base de la gran revolución estética que parte desde el romanticismo hasta llegar al arte de vanguardia del siglo XX. Es el mismo sentimiento por el que Balzac lleva a la muerte al pintor Frenhofer en Le Chef - d'oeuvre inconnu. Muy a menudo, esta obra de Balzac se sitúa en los orígenes de la inflexión artística de la que aquí estamos hablando. Por lo tanto, resulta incomprensible cómo el escritor es reconocido como pionero en este anuncio de una cierta «muerte del arte», mientras el filósofo que ofrece el por qué de esta muerte - sin tomar una posición a favor o en contra - es atacado como enemigo del arte. ${ }^{46}$

Es innegable que Hegel privilegiaba un nivel espiritual liberado de la inmediatez de lo sensible. En la conclusión de la sección dedicada a la relación entre arte, religión y filosofía en las lecciones sobre estética, se dice de manera inequívoca que «la manifestación de la verdad en forma sensible, no es verdaderamente adecuada al Espíritu». ${ }^{47}$ ¿Y no es cierto que cada artista intenta a su manera superar las limitaciones de la materia, los límites del lenguaje, de expresión, etc.? Decir que el arte no aspira a su superación, que no aspira a ofrecerse al Pensamiento, es como aceptar que un filólogo corrija la sintaxis de Rilke o de Celan, con la idea de que la poesía debe ser una expresión lingüística inmediatamente comprensible según cánones pre-establecidos. En realidad, creemos que es el poeta el que crea el lenguaje, y no al revés ${ }^{48}$ y que el arte tiene la capacidad de crear realmente un mundo - el mundo humano - antes de que intervengan las otras formas del Espíritu. Es precisamente este hecho el que permite a Mondrian escribir: «¿El arte se está acercando a su fin? No hay nada que temer. ¿Qué es este — todavía lejano - fin del arte sino la liberación del hombre de la domi-

$45 \mathrm{~W} 14,235 ; 444$.

46 ¿Qué decir pues de las teorías que vieron, no sólo la poesía en la pintura, si no que también les agregaban la música, no en sentido metafórico, sino figuradamente como traducción de los sonidos en colores; cfr. Los textos de Der Blaue Ritter, en: Kandinsky, El jinete azul, Barcelona 2010.

$47 \mathrm{~W} 13,144 ; 80$.

48 Podría ser esta una consecuencia del hecho de que el lenguaje es tratado por Hegel en la Enciclopedia como uno de los productos de la de la Fantasía (cfr. §459) y, de hecho, el mas importante. 
nación de lo material y de lo físico y por lo tanto el acercamiento al tiempo de la equivalencia «materia-espíritu»»»? ${ }^{49}$

Mondrian no sólo continúa literalmente con el discurso por el que Hegel ha sido hasta ahora incriminado como el principal culpable, sino que además en su obra se puede observar una evolución estética, fundamentalmente incomprensible sin una teoría como aquella de Hegel, ya que del simbolismo más profundo y místico pasa a la pureza del signo, como de la oscuridad se pasa a la luz. A menudo se habla de la Teosofía y de su influencia en Mondrian. La cultura de principios del siglo XX estaba impregnada de estas teorías, que sustituían entonces a los grandes sistemas filosóficos del pasado. Fácilmente digeribles, como eran, tenían un poder aún mayor en aquellas capas de la cultura compuestas por personas que no eran filósofos de profesión.

Debemos al historiador del arte de Harvard Yve-Alain Bois una inversión radical del problema relativo a las ideas subyacentes a la revolución abstraccionista. Él considera la lectura de Hegel por parte de Mondrian, un punto crucial en la evolución del artista holandés. ${ }^{50}$ Tal propuesta, novedosa hace unas décadas, ahora y para nuestra satisfacción, llega a ser parte de los manuales de historia del arte. ${ }^{51}$

Las consecuencias figurativas del hegelianismo en la obra de Mondrian (y del grupo De Stijl) van más allá de toda expectativa. Podemos hablar, literalmente, de una traducción de los conceptos hegelianos en «signos plásticos». Hegel hace entender a Mondrian que cada «reposo» o «arresto» y cualquier

49 P. Mondrian, Sull'arte puramente astratta (1926), en: Id., Scritti Scelti, tr.it. de V. Tonon, Treviso 2006, p. 49.

50 Cfr., el ensayo de Yve-Alain Bois, The iconoclast, en: Piet Mondrian, Boston-New York-Toronto-London 1994, pp. 313-372; el historiador norteamericano demostró, con gran cantidad de documentos, que Mondrian no sólo después del primer período juvenil interrumpió su relación con los círculos teosóficos, sino que a medida que su obra y su pensamiento maduraban, se convirtió en su crítico agudo y sistemático. Además de la teosofía, a menudo se habla de la influencia del filósofo holandés Schoenmakers (cfr. por ejemplo Los dominios de lo invisible de G. Sollana, en: El arte abstracto, cit., p. 17; también: Els Hoek, Mondrian, en: De Beginjeren van De Stijl 1917-1922, en C. Blotkamp; tr.it. De Stijl. Nascita di un movimento, Milano 1989, p. 86s), mientras que en realidad, tanto Van Doesburg como Mondrian estaban de acuerdo en excluirlo de De Stijl, precisamente por la incompatibilidad ideológica. Es aún más raro encontrar mención al hegeliano Gerardus Bolland que aunque, como muestra Bois, tuvo mucha más influencia sobre los artistas de lo que se piensa. Carel Blotkamp, además de Bois, señala no sólo una influencia genérica de este filósofo hegeliano, si no la inspiración concreta, por ejemplo, del cuadro De Zuivere Rede (La Razón Pura) del pintor J. De Winter, que apreciaba tanto Van Doesburg (cfr. Theo Van Doesburg, in: De Stijl..., cit., p. 25).

51 Cfr., Hal Foster, Rosalind Krauss, Yve-Alain Bois, Benjamin H.D. Buchloh, Art since 1900: Modernism, Antimodernism, Postmodernism, Vol. 1, London 2011; tr.it. Arte dal 1900. Modernismo, Antimodernismo, Postmodernismo, ed.it. a c. di E. Grazioli, Bologna 2006 , p.149. 
«equilibrio» - nociones en boga en el lenguaje estético de la época- son nociones ilusorias. El signo de la cruz, es decir, la oposición entre línea horizontal y línea vertical, hasta ahora precisamente exaltado por las teorías teosóficas, hegelianamente resulta insuficiente: Mondrian había entendido algo que muchos filósofos hegelianos no habían entendido, o sea que el núcleo de la dialéctica hegeliana no es la negación, sino la negatividad. ${ }^{52}$ Es así que de repente Mondrian deja de buscar el equilibrio, porque el «opuesto debe convertirse en su otro», más que neutralizarse en la mutua negación. ${ }^{53}$

Son estos procesos y estas investigaciones las que conectan directamente a Hegel con la vanguardia y no, como piensa Houlgate, un discurso sobre la naturaleza y las tareas de la pintura. ${ }^{54}$ No es la pintura por si misma, la que puede revelar los secretos de la imagen. De hecho, Houlgate, como buen conocedor de la lógica, cita el pasaje que fundamenta cualquier teoría de la visibilidad en Hegel, sobre la necesidad de la aparición de la Esencia. ${ }^{55}$ Indebidamente, sin embargo, lo reconecta a la pintura, considerando esta última el japarecer por excelencia! ${ }^{56}$ En realidad, es el arte in toto y como disciplina del Espíritu Absoluto lo que es la aparición del espíritu por excelencia, no la pintura. Esto significa prácticamente que el artista está autorizado a moverse como estime conveniente a fin de lograr su objetivo, que es aquel de hacer visible lo invisible. Según sus tesis, se debería decir que el arte de Kandinsky falló en «reconocer la importancia efectiva en la pintura del crear la ilusión puramente visual de formas naturales». ${ }^{57}$ Creo que no se pueda explicar de acuerdo con el Sistema de

52 De ello se lamentaba Karl Rosenkranz desde 1868 (cfr. su carta al The Journal of Speculative Philosophy, II, 1, 1868, pp. 55-56). Sobre la cuestión entre los discípulos de Hegel, cf. F. Duque, Hegel. La especulación de la indigencia, Barcelona 1990, pp. $163 \mathrm{ss}$.

53 Según Bois, Mondrian, de hecho, «repetía esta frase durante toda su vida»; cf. The iconoclast, cit., p. 339 . 61-82.

54 Cfr., S. Houlgate, Hegel and the Art of Painting, in: Hegel and the Aesthetics, cit., pp.

55 GW11, 323; 535: Das Wesen muß erscheinen.

56 Cfr., S. Houlgate, op.cit., p. 75; Que Houlgate mencione aquí la lección sobre la estética hegeliana de 1820-21, donde la pintura vendría llamada el «Scheinen par excellence», tiene un valor demostrativo únicamente filológico - $\mathrm{e}$ incluso éste limitado, precisamente porque se trata de 1820 y no de 1828-29 que habría sido el último curso de estética del cual disponemos. Además de ello, basta señalar que un «aparecer por excelencia» en el Sistema de Saber, puede perfectamente considerarse tanto la Esencia con respecto al Ser, como la Naturaleza con respecto a la Idea, o bien el Hombre con respecto a la Naturaleza, y similares. En la esfera de la filosofía del arte, es el aparecer de la belleza el que cumple este perfecto equilibrio entre forma y contenido. Pero el ámbito estético no se limita a lo clásico o lo bello - concepción racionalista ésta que quizá subyace en el pensamiento estético de Houlgate - sino que tiene la tarea de romper este equilibrio justamente para liberar el espíritu; todo el arte romántico no es más que el desarrollo de esta tentativa de infringir los esquemas de cada aparecer finito y es éste un elemento central que lo sitúa en los orígenes de la abstracción del siglo XX.

57 Ibid., p. 74. 
Saber, que Hegel habría pretendido del arte o de la pintura la producción de una ilusión de formas naturales. Creo que ésto no se puede explicar de acuerdo con el Sistema de Saber, ni aunque hubiera un testimonio manuscrito por Hegel mismo. Sin embargo, podemos recordar a quien conecta «arte»e «ilusión» estas palabras de Hegel: «El arte le quita la apariencia y la ilusión de este mundo malo, efímero, a aquel contenido verdadero de los fenómenos, y les da a éstos una realidad efectiva superior, hija del espíritu». ${ }^{58}$

\section{ICONOCLASTIA ENDÓGENA DE LA IMAGEN EN EL ESPÍRITU SUBJETIVO}

En lo que sigue, me gustaría destacar uno de los nudos principales sobre la cuestión de la imagen en la doctrina del Espíritu Subjetivo. Querría tomar la Gran Lógica como punto de inicio para luego seguir el movimiento que se reproduce en la Psicología hegeliana y se refiere al Aparecer y a la disolución del Aparecer.

La Lógica está llena de anticipaciones de posteriores desarrollos que muy a menudo Hegel indica como tales, en la dificultad general de presentar algo altamente abstracto que sólo más tarde vendrá desplegado. ${ }^{59}$ Leamos: «La aparición [Erscheinung] contiene a ambos: al fundamento simple [Grund] y al movimiento de disolución [die auflösende Bewegung] del universo que aparece [des erscheinenden Universums], cuya esencialidad es aquel fundamento simple». ${ }^{60}$

Sobre la noción de fundamento no es necesario detenerse ahora. ${ }^{61}$ Tan sólo tengamos en cuenta una cosa: su ponerse como primero precisamente porque viene al final; su ser el abismo disolvente de las determinaciones de la reflexión y con ello también su razón de ser, su ser ambigüedad altísima y paradójica mientras se presenta al mismo tiempo como movimiento del fundar y movimiento hacia la muerte (que Hegel deja entrever en la expresión ambigua zu Grunde gehen, «ir» al fundamento, o bien morir). No es casualidad que, en la citada frase, por lo tanto, esta noción del fundamento se ha puesto como la esencialidad del «movimiento de disolución del universo que aparece». Es a este movimiento

58 W13, 22; 12.

59 Precisamente en la parte que aquí nos interesa, Hegel habla de la importancia y del sentido de la dialéctica entre forma y contenido en las obras de arte: cf. el $\S 133 Z$, donde se habla de la «forma justa» de la obra de arte, dándonos así una confirmación del hecho de que las determinaciones de las que aquí se trata son de hecho aquellas que, en otras esferas del conocimiento, se mueven internamente en la Cosa.

$60 \mathrm{GW} 11,345 ; 562$.

61 Remitimos al capítulo ya mencionado de F. Duque, en su libro Il fiore nero; para un análisis más detallado y una interpretación que introduce este principio lógico en nuestra actualidad, véase su ensayo publicado recientemente: Come dare ragione del Principio di ragione, en: Teoria. Rivista di filosofia, XXXIII (2013) 1, Hegel. Scienza della logica, Pisa 2013, pp.101-128. Véase también el trabajo de L.A. Manfreda, Il circolo e lo specchio. Sul fondamento in Hegel, Genova 2012. 
al que queríamos llegar. Porque creo que es precisamente aquí donde se funda, por un lado la necesidad ontológica que rige todo el camino del Espíritu Subjetivo $^{62}$ y por otro la especificidad del ser de la imagen, como aparecer que hace ser la Esencia y, precisamente por ello, debe desaparecer. ${ }^{63}$

Toda la vida de la imagen, es decir, su vida e incluso su muerte - su ser, su ser-ahí, su significado, todo lo que le concierne y todo lo que ella es - viene expresado aquí de manera abreviada. La imagen debe su ser a ambos, al fundamento y al movimiento de disolución del universo que aparece. Por lo tanto no vacilaría en decir que la imagen es imagen sólo en su aparecer y en la disolución espontánea de este mismo aparecer.

Precisamente porque la totalidad del Espíritu Subjetivo participa de aquel camino denominado Auflösung des empirischen Zusammenhangs der des Bestimmungen Gegenstandes, y porque precisamente la facultad de representación constituye una de las actividades más importantes para su vida espiritual, es ahí donde queremos enfocar nuestra atención.

La conexión empírica a la que apenas se hace referencia, es aquella teorizada por los empiristas británicos con el nombre de «asociación de las ideas»o «de las imágenes», ya que para los empiristas como Hume cada «determinación del objeto» no es más que una imagen mental, y cada idea no es más que un conjunto de imágenes. Se hablaba precisamente de la idea del rojo (representación universal) que resulta de la asociación de las imágenes concretas del rojo de las flores, por ejemplo. Como señala Hegel, de este modo se piensa a la inteligencia como un espectador pasivo a quien le es suministrado todo el material necesario. Para él, sin embargo, la inteligencia no es pasividad, sino espontaneidad.$^{64}$ Decir que la inteligencia es espontánea significa identificarla con un «enlace libre y subsunción de ese cúmulo bajo el contenido que le es propio» (§456), a través del ejercicio de la fantasía. Contrariamente a lo que se piensa, Hegel no sólo no

62 Llamada, precisamente, la [von der Intelligenz ausgehende] Auflösung des empirischen Zusammenhangs der mannigfaltigen Bestimmungen des Gegenstandes, es decir, la [procedente de la Inteligencia] disolución de la conexión empírica de las variadas determinaciones del objeto; $\S 456 \mathrm{Z}$.

63 En la Lógica, una sección se llama precisamente Auflösung der Erscheinung, disolución de la apariencia. Junto a la disolución de la cosa [Die Auflösung des Dings] es el único momento en el cual se trata de la necesidad de la «disolución» de algo como momento último de un proceso. Así como de la disolución de la cosa se pasa a la apariencia, así de la disolución de la apariencia se pasa - ya no a algo, sino a una relación, y precisamente- a la relación esencial, y la relación en general, creo que debe ser entendida como un índice de libertad cada vez mayor. Por otro lado, el camino fenomenológico de la conciencia pienso que es suficiente para convencernos del hecho de que la relación con los objetos es lo esencial y no los objetos como tales.

64 Adquisición filosófica ésta, de atribuir a Reinhold y a su teoría de la representación; vease K. L. Reinhold, Versuch einer neuen Theorie des menschlichen Vorstellungsvermögens, Jena 1789. 
era hostil a las teorías románticas sobre la importancia de la imaginación, sino que absorbió todos los aspectos — como precisamente el ser una facultad de la espontaneidad - asignándole un puesto central en el Sistema del Saber. ${ }^{65}$

La fantasía puede ser dañina al máximo cuando está vacía de contenido, o bien puede ser un instrumento sólido de la inteligencia cuando ésta última posee la conciencia y el dominio sobre sus propios contenidos. Todas las «estaciones» del Espíritu Subjetivo adquieren un valor diferente si son revisitadas por el hombre «formado», que sería el artista para Hegel: un hombre que, antes, aclara la Idea, y sólo en un segundo momento regresa a plasmar la sensibilidad de acuerdo a esta Idea. ${ }^{66}$ De ahí la importancia del término Er-innerung, recuerdo, en la vida del Espíritu. «Recordar», hegelianamente, significa ensimismarse, volver a la interioridad más propia, reencontrar el material de la intuición y fijarlo en imágenes, de otro modo fugaz y accidental, mero dato en bruto de la experiencia. ${ }^{67}$

En las lecciones sobre el Espíritu Subjetivo encontramos el mismo procedimiento sorprendente: al igual que en la Lógica, el fenómeno a través de la dialéctica interno/externo y la adecuación entre forma/contenido, pasa a su disolución. Precisamente aquí intuimos el proceso lógico que regiría una ontología de las imágenes. Leemos ahora en la Enciclopedia: «en cuanto que la Inteligencia produce esta unidad de universal y particular, de interno y externo, de representación e intuición, y de esta manera reconstituye, como ya verificada, la totalidad que estaba presente en la intuición misma, la actividad representativa se realiza en sí misma, en la medida en la que es imaginación productiva. Esta última constituye el elemento formal del arte; puesto que el arte expone lo que verdaderamente es universal, la idea, en la forma de existencia determinada sensible [in der Form des sinnlichen Daseins], de imagen». ${ }^{68}$ Por supuesto, el

65 «Un puesto central», de todos modos, no significa una exaltación incondicional, ni una desmesurada confianza en su capacidad productiva, como alguno sostiene (Cfr., J.A. Bates, Hegel's theory of imagination, New York 2004). Significa determinar su puesto y sus funciones precisas en el gran organismo del Espíritu.

$66 \S 449 \mathrm{Z}$ : «A menudo nos imaginamos que el poeta, como el artista en general, no pueda proceder más que por intuición. No es para nada así. Un verdadero poeta debe, por el contrario, antes y durante la ejecución de su obra, meditar y reflexionar; sólo de esta manera puede esperar extraer el corazón y el alma de la Cosa de todas las exterioridades que la envuelven, desarrollando así organicamente la intuición que él posee».

67 Pensamos, ¿cuál es la imagen universal de una palabra como «margarita»? Sin duda es la de una flor para un campesino; pero también la de un plato típico para un napolitano, mientas que para un erudito es la pureza goethiana en el Faust o la barbarie nazi en el Todesfuge de Celan, etc. Sea lo que sea, non es la imagen que lleva consigo la idea (come pretendía la antigua mnemotecnica) si no su empleo específico por parte de la Inteligencia formada, donde la palabra «formada» (que en alemán sonaría ge-bild-et) no puede ser todavía pensada en relación a la imagen $($ Bild $)$, sin recaer una vez más en una banal asociación de imágenes.

68 Cfr., la conclusión del $\S 456 Z$. 
arte es el primer nivel de la esfera del Espíritu Absoluto, pero este absoluto parece ser sólo nombrado para absolver nuestros pecados y principalmente el de querer pensar inmediatamente la Verdad. El (pseudo) silogismo es simple: el arte está en el Absoluto, nosotros hacemos arte, luego estamos en lo Absoluto. Pero aquel Absoluto y aquel Arte no indican lo que nosotros hacemos, que sólo formalmente es arte; aquellos absolutos indican el contenido supremo: Dios, y no nuestro pasatiempo - bien sea «arte» o aforismos «filosóficos».

Para entender lo que sucede en la doctrina del Espíritu Subjetivo primero debemos visualizar el conjunto. En el Espíritu Teórico, primera sección de la Psicología, encontramos esta división tripartita: a) intuición b) representación c) pensamiento. La representación se divide, a su vez, en tres etapas: a) recuerdo (Erinnerung) b ) imaginación (Einbildungskraft) c) memoria (Gedächtnis) .

En la primera tríada, se ve claramente que la imagen (en cuanto representación) es el medio entre la intuición y el pensamiento. Resulta muy interesante el hecho de que la facultad de representación, para Hegel, abraza las otras facultades tradicionalmente presentadas separadamente, es decir, la memoria y la imaginación.

La imagen emerge del recuerdo de la intuición sensible y emerge como una síntesis superior respecto a aquella intuición. La imagen es una verdad superior para el Espíritu a la mera sensibilidad. Sea dicho, de paso, que «imagen», para Hegel, no es cualquier cosa vista. Aquello que es visto, no es más que un dato, una excitación de los nervios ópticos, de la misma manera que aquello que se toca o aquello que se oye. $\mathrm{Y}$ al igual que aquello que se toca no es necesariamente una estatua, aquello que se oye no es necesariamente música, así aquello que se ve no es necesariamente una imagen. De esta simple constatación, debemos sin embargo deducir lo siguiente: que la imagen no es un producto natural que el hombre recibe del exterior, gracias a los sentidos; ni es tampoco la mezcla que sin embargo nos proponen los estudiosos de la percepción. No es, en fin, ni una cosa (ein Ding), ni una copia de una cosa (ein Abbild eines Dinges); pero eventualmente es una Cosa-del-pensamiento (eine Sache). Acertadamente el estudioso de las imágenes Melot, dijo que antes de nada la imagen es todo aquello que está delimitado por un marco, en el sentido que es un «pedazo de vida arrancado de lo real». ${ }^{69}$ Nosotros, sin embargo, no necesitamos el marco de madera o de otro material; el marco lo pone el Espíritu y es que precisamente lo que Hegel entiende cuando dice que la cosa (das Ding) en la imagen adquiere el

69 Cfr., Michel Melot, Une brève histoire de l'image, Paris 2007; tr.it. Breve storia dell'immagine, Tesserete 2009, pp. 19ss. 
tiempo y el espacio de la conciencia. ${ }^{70}$ Operación, ésta, que transfigura completamente el mundo y que tiene lugar todos los días delante de nosotros.

Habría muchas cosas que tratar en detalle acerca de esto, pero se puede entender que es difícil hacerlo aquí donde solo se pretende dar una visión del conjunto de un tema actual y de cómo ésta encuentra suelo fértil en el idealismo hegeliano. Por lo tanto, pasemos al punto más importante que se refiere al tema de la desaparición de la imagen.

Como hemos visto, la imaginación, facultad productora de imágenes, es el medio entre el recuerdo y la memoria, y los tres momentos conjuntamente constituyen la facultad de representación. Esto significa que la representación puede tener una de estas formas: como recuerdo puede ser una experiencia vivida en el pasado que ahora recobra vida en la inmediatez del sentimiento. Los recuerdos personales no son necesariamente imágenes. De hecho, aun cuando aparecen como tales, es difícil fijar la mirada sobre ellos como si fueran pinturas colgadas en una pared, o como si se estuviera hojeando un álbum de familia. Son «imágenes» fluidas que se ofrecen a la vida presente como el sustrato sobre el que trabajar y que sirven para re-conocer aquello que es familiar en su forma inmediata. La imaginación, en sus diversas actividades, produce imágenes heterogéneas: una imagen que actúa como índice de toda una serie de otras imágenes (a la manera de la asociación de ideas de los empiristas), una imagen-símbolo, o bien un signo, o incluso una «imagen poética» que sería otro tipo de «conjunto de imágenes» en proceso, ${ }^{71}$ también éstas son fluidas y, de la misma manera que el recuerdo, pretenden capturar la vitalidad no del pasado acontecido, sino del que siempre acontece. ${ }^{72}$

Llegamos finalmente a la memoria (Gedächtnis), donde las cosas se complican fatalmente para las imágenes. La primera cosa anómala que este tipo de memoria pone en evidencia es que mientras que en todo el proceso formativo del Espíritu Subjetivo se da lugar a una lucha por aumentar la libertad en los fenómenos, aquí, de repente, a un paso del pensamiento, Hegel se moviliza para devolver la dignidad a aquello de lo que «últimamente se ha puesto de moda hablar con desprecio», y que no es otra cosa que la memoria mecánica. ${ }^{73} \mathrm{La}$

$70 \mathrm{Y}$ es así que viene «arrancada de lo real», substrayéndose por lo tanto del tiempo y del espacio físico, o bien como diría Bergson, no simplemente físico, sino de la Física, es decir, del «tiempo» y del «espacio» divisibles según las unidades de medida abstractas del Intelecto.

71 Hegel cita para una ilustración similar la poesía de Goethe sobre Mahoma: cfr., W13, 523ss.; 300ss.

72 Pensamos en este caso en la «frescura» de ciertas poesías antiguas: la Divina Commedia habla de la situación política en la Toscana de entonces, pero de ello sólo el historiador puede hacerse una idea; cuando canta, en cambio, sobre la «luce intellettual, piena d'amore» (Par.XXX,40) se trata no de un «recuerdo» del pasado si no de un eterno presente.

73 Piénsese a la afinidad lingüística — que el propio Hegel pone en evidencia - entre el Pensamiento (das Denken, der Gedanke) y la memoria (das Gedächtnis); cfr., §464A. 
espontaneidad de la fantasía, de repente viene superada por el mecanismo rígido y vacío de la repetición de los signos lingüísticos, de las palabras y de los nombres. ¿Cómo podría surgir un silogismo correcto, si en lugar de la determinación de la causalidad, por ejemplo, yo tuviese siempre en mente las bolas de una partida de billar, de acuerdo con el famoso ejemplo de Hume? Es sin embargo un hábito empírico esperar siempre que el efecto sigue a la causa, pero ningún hábito podría explicar el acto mismo por el cual la inteligencia se eleva a la simplicidad de la ley y al reconocimiento de la necesidad. Para que este salto tenga lugar, es necesario que todos los contenido imaginativos se cancelen. El intelecto no puede legislar con bolas de billar, ni con manzanas que caen sobre la cabeza de alguien. Entre dibujar un cuadrado para la construcción o la división de los campos, por un lado, y los teoremas de Euclides, por otro, existe un abismo insalvable que sólo el pensamiento racional y la imaginación-en cuantomemoria iconoclasta, podría explicar.

Pero incluso una simple operación del Espíritu, como es la lectura, por ejemplo, presupone una capacidad eminentemente iconoclasta: las imágenes deben desaparecer para dejar su lugar a los signos de la inteligencia. ${ }^{74}$ Si por cada palabra pensáramos en su contenido sensible (es decir, si pensáramos en imágenes) cualquier lectura sería imposible. ${ }^{75}$

Así es como funciona la memoria hegeliana: opera sólo con este material desmaterializado. Por lo tanto, el signo ha de ser considerado en un nivel más

74 En el juvenil Espiritu del cristianismo y su destino, Hegel puso ya esta idea en el centro de su reflexión con un ímpetu iconoclasta que más tarde se atemperó lentamente por las soluciones sistemáticas de su filosofía. Hablando de la simbología de la última cena, Hegel dice que puede ser comparada con la relación entre pensamiento y palabra. Al igual que en la palabra el pensamiento se convierte en $\cos a$, y para evitar esto, lo ideal sería que con su comprensión el texto desaparezca físicamente del todo, así en el pan y el vino que, precisamente porque se disuelven, dejan espacio a la memoria; cfr. W1, 368. Surge una cuestión importante que debemos, sin embargo, afrontar en el futuro: es decir, las raices luteranas de su iconoclastia. En realidad, aunque pueda parecer obvio, observando más de cerca las tradiciones protestantes, la cuestión iconoclasta no aparece unívoca (véase por ejemplo el excelente estudio de C. M. N. Eire, War Against the Idols: The Reformation of Worship from Erasmus to Calvin, Cambridge 2003) y por lo tanto la posición hegeliana debe ser afrontada como una interpretación más amplia de la doctrina luterana y, en consecuencia, también conectada inmediatamente a su filosofía de la religión en general.

75 Uno de los ejemplos más recurrentes en Hegel es el de la palabra «león»; con ella no necesitamos ninguna intuición sensible. La Inteligencia ha puesto como contenido metafórico de la palabra «león», el valor, la fuerza, etc., mientras que un león, visto de cerca, puede ser viejo, estar enfermo, etc. Las corridas de toros en España pueden resultar un espectáculo inapropiado a la sensibilidad contemporánea, pero el autorretrato de Goya como torero será siempre un símbolo de valor y de dignidad, una representación de la nobleza del ánimo español. ¿No vale eso también para todos los símbolos griegos, signos de tal idealización de la Inteligencia? ¿No es la misma Grecia un producto puro tal de la inteligencia, como la Italia de Goethe? 
alto que el símbolo, incluso siendo menos rico desde el punto de vista figurativo. Incluso hoy, y después del nacimiento de la semiótica, del arte conceptual, o después de la difusión de las teorías científicas a un vasto público - cosas que habrían debido hacernos más familiar el valor del signo - hay pensadores que creen que pueden permitirse hacer ironía sobre las posiciones de Hegel: en realidad no hacen más que expresar el sentido común, inmerso como está en la sensibilidad y hambriento de figuras e imágenes.

Hemos llegados así al cumplimiento de la representación, que desde la intuición nos hace llegar al pensamiento. Y es aquí donde se encuentra el núcleo explosivo del pensamiento hegeliano sobre las imágenes, donde emerge aquel concepto que nosotros queremos llamar iconoclasia endógena. Como hemos dicho, para que la figura del recuerdo-imagen pase a ser Cosa-del-pensamiento, debe atravesar las etapas de «destilación» de la imaginación. En el camino del Espíritu Subjetivo está siempre el sujeto que se eleva a un nivel mayor, pero también está la Cosa que se presta a las estructuras de su entendimiento.

En la memoria hegeliana, se da el cruce de la formación (die Bildung) del sujeto con el elemento an-icónico (das Bildlose) de la imagen. No es sólo el sujeto que «abstrae», andando de la sensibilidad al intelecto, pero - seame permitido un juego de palabras - es también la imagen (Bild) que en lo an-icónico (Bildlos) cumple su destino (das Los des Bildes). Veamos más de cerca lo que sucede.

Nos encontramos en el párrafo 462 de la Enciclopedia de las ciencias filosóficas. Es el segundo párrafo de la sección dedicada a la memoria-Gedächtnis. El párrafo anterior, que introduce el tema, nos habla de la primera de las tres formas de memoria, la así llamada namenbehaltenden, es decir, aquella que retiene el nombre. ${ }^{76}$ El párrafo que sigue es aquel en el que nos detendremos, tematiza en cambio la tercera forma de memoria, la memoria mecánica. Entre estas dos formas se sitúa de la «memoria reproductiva», das reproduzierende Gedächtnis.

En este párrafo encontramos la primera de las tres «tesis iconoclastas.» Las otras dos siguen en la nota (Anmerkung) que Hegel añadió en la edición de 1830. La memoria reproductiva, escribe Hegel, «tiene y conoce la Cosa en el nombre y, con la Cosa, tiene y conoce el nombre, sin intuición ni imagen». ${ }^{77}$ Veamos también las otras dos: «El nombre en tanto lo entendemos, es la simple

76 Una vez más, no hay que subestimar el sentido crítico y penetrante de Hegel. La memoria que retiene el nombre, no es simplemente la que llamamos, no sin desprecio, «memoria mecánica». Retener el nombre, de alguna manera, significa ya pensar, o al menos estar ya en el pensamiento. No se trata de un simple dato empírico, porque «el nombre, dice Hegel, es así la Cosa tal como ella está presente y tiene valor en el reino de la representación»(§462). Esta tesis expresa bien el pensamiento hegeliano: el hombre, en la formación de sus representaciones, no tiene ningún material-cosa, si no sólo nombres.

77 «Das reproduzierende Gedächtnis hat und erkennt im Namen die Sache und mit der Sache den Namen, ohne Anschauung und Bild»; cursivas nuestras. 
representación anicónica. Es en el nombre donde pensamos». ${ }^{78}$ Luego, hacia el final de la misma nota: «Más bien [lo correcto es que] la memoria ya no tiene que ver con la imagen, la cual está tomada del ser determinado inmediato y no espiritual de la inteligencia, o sea de la intuición». ${ }^{79}$

Estas tres tesis iconoclastas son el corazón de una ontología de la imagen hegeliana, porque a partir de ellas se puede determinar el estatus ontológico de la imagen en general, y de la imagen en cuanto producto artístico. Alguno podría objetar que aquí se trata no de la imaginación, sino de la memoria, y que por lo tanto la referencia lo anicónico no se aplica a la producción de obras de arte. Pero esto no es exacto por varios motivos: antes de nada, lo más importante en este tipo de tratamiento es que la memoria no sólo es parte integrante de la facultad de representación, sino también su punto más alto, la síntesis entre recuerdo e imaginación. Esto significa, in primis, que cada vez que formamos una representación integral de la Cosa, esta sigue estos momentos y «se da» al pensamiento como resultado mnemónico, imagen simple, imagen anicónica, imagen que no es imagen.

Lo que Hegel teorizó sobre la imagen, y que es absolutamente revolucionario en comparación con la historia que siguió hasta nuestros días, es lo siguiente: que la imagen no sólo es un medio que «encarna» un sentido, que re-presenta algo distinto a si mismo, sino que, al hacerlo, sale y se pone, aparece y desaparece, se impone y se disuelve, según el orden de su propia naturaleza, según una onto-lógica que le es propia. Sin esta movilidad interna de la imagen, es inútil teorizar sobre las características de la verdadera imagen contra la posibilidad de que esta se convierta en ídolo. Las dos grandes corrientes de pensamiento sobre la imagen (la bizantina y la contemporánea) tratarán en vano de establecer un criterio válido de verificación. El más alla de la imagen que todos entienden como un requisito necesario para que la imagen no sea engañosa, viene explicado mucho mejor por el principio hegeliano de la negatividad (relacional) del Espíritu y del impulso interno que empuja a cada figuración o imagen hacia su fundamento.

Este impulso se manifiesta como reconocimiento consciente de un momento de la identidad que de otro modo sería traumático, es decir, su ser en si mismo distinto de si mismo. Retornando una vez más a los temas ya vistos, entendemos mejor que el signo, por ejemplo, acoje su finitud, su ser arbitrario, en una manera más sosegada, sin obstinación: es distinto de sí mismo y manifiesta inmediatamente esta alteridad. Es por eso que se ofrece mejor al pensamiento. No «da a

78 «Der Name, indem wir ihn verstehen, ist die bildlose einfache Vorstellung. Es ist in Namen, daß wir denken»; cursivas nuestras.

79 «Vielmehr hat es das Gedächtnis nicht mehr mit dem Bilde zu tun, welches aus dem unmittelbaren, ungeistigen Bestimmtsein der Intelligenz, aus der Anschauung, hergenommen ist»; cursivas de Hegel. 
pensar» como el símbolo kantiano, pero se da al pensamiento y se convierte en un instrumento del Espíritu. El símbolo en cambio, siendo sin embargo rellenado en su contenido por la Inteligencia, se presenta como autosuficiente, e incluso él mismo como pensamiento.

Todo esto, no debe ser univocamente aplicado a las artes. No tiene el objetivo de indicar lo que las artes tienen que hacer, sino aquello que es independientemente de lo que el artista o el espectador quiere. En resumen, se podría concluir a partir de las observaciones anteriores que cuanto más realista es la obra de arte, más falsa es, más ídolo es. Ejemplo notable: la fotografía. No sólo no produce simplemente ídolos y falsos dobles de la realidad, sino que precisamente por esta su adhesión icónica al dato inmediato, al natural, es capaz de subvertir más facilmente el orden de la representación. Por ello tiene razón Cacciari al sostener que «la fotografía cuanto más realista, más abstracta es», ${ }^{80}$ y que un gran fotógrafo español como Chema Madoz viene a confirmar con su trabajo. Cacciari, sin seguir la doctrina hegeliana, intuye y se centra en las mismas relaciones que son fundamentales para Hegel, es decir el nexo que une recuerdo y memoria de una manera no lineal, no unidireccional y adialéctica, sino al contrario poniéndolas en tensión. Ahora bien, el punto de tensión sobre el que ambos se apoyan es la imagen, y es esta la contribución hegeliana que durante mucho tiempo ha permanecido a la sombra.

Breve aunque esencial, la profundización de la imagen en Hegel nos pone delante de estas novedades absolutas:

a) El hecho de que la imagen no nazca de la reproducción de la percepción externa, sino del ensimismarse del Espíritu en forma de recuerdo - lo que explicaría bien un aspecto esencial del arte desde 1945 hasta hoy (piénsese a la relación entre memoria e imagen en la obra de A. Kiefer o G. Richter, por ejemplo).

80 Cfr. M. Cacciari, Il «fotografico» e il problema della rappresentazione, in: Fotologia 5 (1986); en: C. Marra, Le idee della fotografia. La riflessione teorica dagli anni Sessanta a oggi, Milano 2001, pp. 340ss; es curioso que en este ensayo Cacciari se centra en la misma problemática de la relación entre representación y memoria, con comentarios muy similares a los nuestros, en cuanto a la necesidad de la imagen de superarse a sí misma en el deber de ser asumida por la memoria: «Y añadiría un aspecto de gran problemática y dramaticidad de la fotografía: que en cada fotografía se muestra también la ulterioridad constante de la memoria; la ofuscación al límite en la que todos los recuerdos se desvanecen en la memoria, sin agotarla nunca. Esta gran problemática de la memoria con respecto a los recuerdos me parece que es la luz que da fuerza a los grandes testimonios (...) del arte de la fotografía» (Ibid, p.344). Y en conclusión, el filósofo italiano señala una cosa que nos hace pensar en nuestra descripción de la negatividad relacional, es decir, el hecho de que a través del medio (la fotografía, y por lo tanto la imagen) el recuerdo se mantiene en «tensión continua e irresoluble» con la memoria. 
b) El hecho que la imagen - a través de sus declinaciones (Bild, Form, Gestalt , Abbild, Vorstellung, etc.) - reviste todas las formas del Espíritu ${ }^{81}$ - lo que significa que estamos obligados a hacer frente con la imagen en cada nivel de conocimiento.

c) El hecho de que la imagen revista todas las formas del Espíritu, sin embargo, no significa que estas formas sean representaciones sensibles (que por ejemplo, en el arte debieran ser figuras naturales o formas de objetos ya existentes). De hecho, es la profundización en aquello de que es la imagen lo que nos permite también formular - finalmente y por primera vez - una justa teoría iconoclasta, en ciertos aspectos ya presente en la historia de la humanidad, como puso en evidencia Besançon, pero casi siempre confusa, o a nivel teórico (entendida como «racionalismo»), o a nivel práctico (con la destrucción material de las obras de arte, es decir, el vandalismo).

Esta extraña especie de iconoclastía creo que es la adquisición más preciosa del pensamiento hegeliano sobre las imágenes, y no encaja en ninguna de las categorías desarrolladas antes de Hegel, sino después, y en esto está también su actualidad. Esta especia de iconoclastía filocálica — porque se trata de una disolución de las imágenes por amor a la Imagen - proponemos llamarla iconoclastía endógena de la imagen; endógena, ya que se desarrolla desde la imagen y dentro de la imagen misma, mostrando así, en modo apagógico, la inadecuación de lo finito. ${ }^{82}$ Con esto, la imagen se convierte, a través de su propia traza iconoclasta, en una promesa de retorno (de Heimkehr - o como dice Hegel de total regreso $^{83}$ ) de lo finito a su fundamento- que sólo el Pensamiento puede y debe realizar.

HARIS PAPOULIAS es investigador postdoctoral en la Università del Piemonte Orientale,

Líneas de investigación:

La noción hegeliana de Bildlose Vorstellung y la cuestión de la iconoclastia.

Publicaciones recientes:

Thanàtô thànaton patêsas. Prospettive estetiche del problema teo-logico della morte di Dio in Hegel, in: Crocifissioni, Davar 2009/2010.

81 Excepto la ultimísima, que no es la filosofía en general, como se dice a menudo, si no

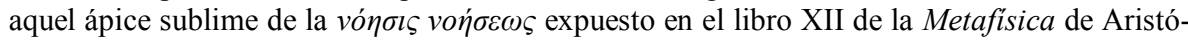
teles.

82 Vittorio Hösle habló de la extraordinaria lógica de la forma apagógica en la prueba cosmológica reformulada por Hegel y que con la imagen, como nosotros la entendemos, comparte el mismo mecanismo de la negatividad, en el que lo finito se lleva a reconocer - y con ello a negar - su finitud, poniendo su propio fundamento en lo Absoluto; cfr. Hegels System. Der Idealismus der Subjektivität und das Problem der Intersubjektivität, 2 voll., Hamburg 1987; tr.it. Il sistema di Hegel, a c. di G. Stelli, Napoli 2012, p. 267.

83 W17, 411: «Totale Rückkehr des Geistes in sich selbst». 
R.M.Rilke e la Terza Cosa. Astrazione e morte dell'arte come compimento della sua essenza, in: L'io e la scrittura, Davar 2007/2008.

Dirección electrónica: haris.papoulias@yahoo.it 